\title{
VERIFICATION OF SELECTION METHODOLOGY FOR ETICS REMEDIATION MEASURES
}

\author{
Ing. Marek Petro, Ph.D; Doc. Ing. Nad'a Antošová, Ph.D.
}

\begin{abstract}
Technology for ETICS repair information are unsystematic, they are narrowed down to remediation of cracks plaster, and also solutions aesthetic character shortcomings or mechanical damage. The method of choosing remediation ETICS failure is usually based on a subjective decision. The research was mapping criteria according to which there is a choice of remediation measures and surveys their importance. When choosing remediation, results were used from previous analysis of available technologies and databases remediation measures. In the experiment was verified methodology of selection based on preferred criteria, expressing the impact of remediation methods on the life of ETICS. In the conclusions are set out shortcomings-stage decision-making process and the reasons for the application of multicriteria decision model.
\end{abstract}

Key words: ETICS, repair,

\section{INTRODUCTION}

The term and form of construction remediation relate mainly with their technical condition and the actual remaining durability. Remedial measures should be planned so that the construction would preserve required rate reliability at minimum costs for maintenance, repair or reconstruction. In practice, most of the technological solutions on the ETICS remediation are beginning to plan at a time when the failures are identified on the construction. In fact, the cost of secondary repair solution, protection of constructions implemented before the development of construction and implementation failures are a fraction of the total costs invested for the reconstruction or renovation of the work [1]. The same principle approach to the issue also covers the construction of thermal insulation composite systems. The current view of solution the ETICS shortcomings is narrowed to the area of identification failures, finding the causes of failures and the subsequent learning from mistakes which consists in adjusting the normative principles (adjusting the policy design, the technological rules, adjusting the principles of implementation, maintenance ...). Information about repair technologies are unsystematic, narrowed down to cracks remediation of the final layer, to address shortcomings of aesthetic character, or lack of mechanical damage. Even if there is occurrence of any repair technology of ETICS failures, the manner of their selection is usually based on a subjective decision more or less erudite owner or building manager.

\section{METHODOLOGY OF WORK}

The basic hypothesis of this work is the selection of appropriate remediation technologies for specific ETICS problem on a number of factors, i.e. based on the criteria and conditions for implementation. The linkage exists among particular criteria and we assume their reflection in the result. However, they often act against each other, they are mutually exclusive, or where appropriate, cumulative. The goal of efficient design is achieving the acceptable consistency. Each of the criteria requires deeper analysis, comprehensible expression of the content with the possibility to respond on meet criteria, and express the importance of criteria - to determine the degree of preference and achieve an objective or an acceptable compliance. The entry conditions for a proposal on the issue of the use of possible remediation technologies are defined in the database of remediation intervention. The entry conditions depend on the extent of damage, the actual thermo-technological properties of the failure type, and the possibility of achieving the quality of implementation, comply with the climatic conditions during the repair implementation, security options or lifetime extension, achievement of the required or improved 
thermo-technological properties. The general principle: the wider range conditions will suit the proposal of remediation measure, the greater functionality will be guaranteed.

\section{CRITERIA}

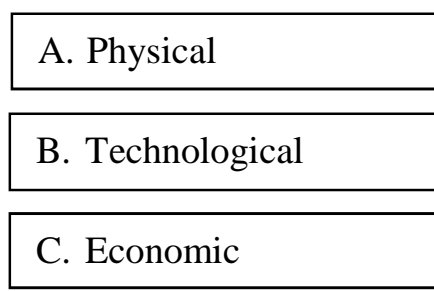

THE ENTRY CONDITIONS

1. Marginal conditions

2. Materials database

3. Technologies

Fig.no.1: Statement of the linkages between criteria and entry conditions of the selection [Author]

Excessive favouritism of one group of criteria or suppression of other group generally results in the distorted information, i.e. inappropriate, uneconomical and incorrect choice. The research work therefore consisted in criteria survey, according to which there is a choice of remediation measures and in the importance survey, which is given to an individual criteria. The decision-making process for selecting the repair technology includes a number of factors (not in order of importance):

B Intervention price

B Labour intensive repairs, remediation,

B Fulfil the functional requirements of ETICS with the identified failure,

B Extent of the failure,

B ETICS age,

B Lifetime of remediation intervention,

B Economic efficiency and more...

In principle, each factor is the expression of physical properties set of ETICS, technological conditions and restrictions set at implementation of remediation measures that stand in opposition to the economic aspect. Economic point of view can be expressed by the lifetime of carried out intervention or by extension of the age ETICS after the remediation measures [5]. In cases where a subjective decision depends on several criteria, methods of multi-criteria evaluation are most frequently used in technical sciences, which are, for example, paired comparison of the importance of individual criteria [4].

In the long term research of preferences of the individual criteria importance that were reflected by the owners or managers of buildings with ETICS construction, the importance of each criterion emerged according to the following table (according to specification criteria [5]):

\begin{tabular}{|l|l|}
\hline \multicolumn{1}{|c|}{ Name of criterion } & $\begin{array}{c}\text { Importance } \\
{[\%]}\end{array}$ \\
\hline \hline Mechanical resistance and stability of ETICS & 19.44 \\
\hline Thermo-technical requirements & 19.44 \\
\hline Volume change & 9.72 \\
\hline Labour intensity of remediation intervention & 8.33 \\
\hline Conditions of implementation & 5.56 \\
\hline Compliance with the original construction and & 1.39 \\
\hline
\end{tabular}




\begin{tabular}{|l|l|} 
remediation intervention & \\
\hline Lifetime of technology intervention, & 18.06 \\
\hline The cost of further maintenance & 2.78 \\
\hline Age and lifetime of ETICS & 15.28 \\
\hline
\end{tabular}

Scheme no.1: Output from the applied research of importance preferences of the criteria for the selection of remediation technologies [5].

It follows from the above such a method of selection of remediation measures, which prefers technical indicators of ETICS obtained after intervention and further durability of the building construction.

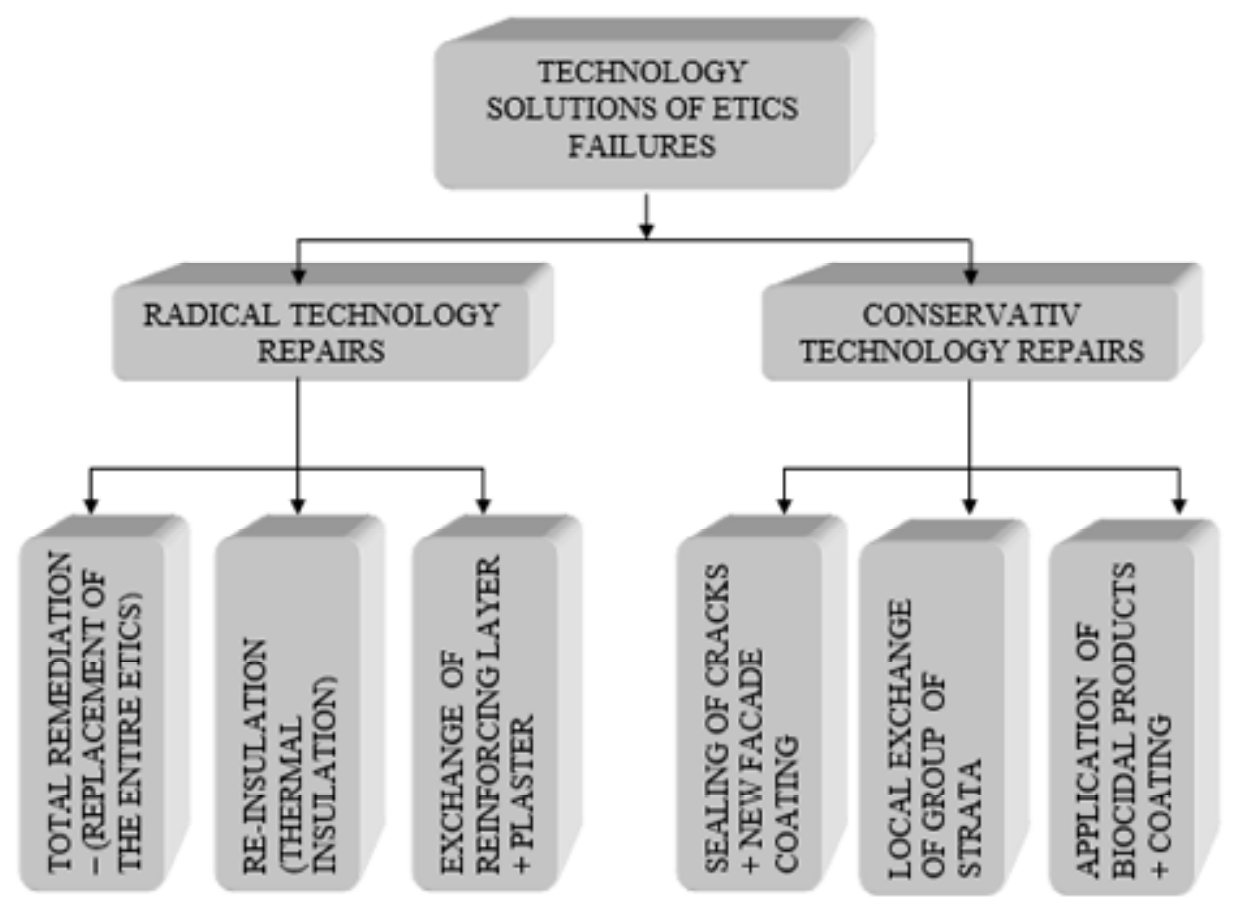

Fig.no.2: Scheme for the selection of remediation measure [Author]

Analyzed and summarized technologies were used in determining the impact of technology choice on the lifetime of ETICS, suitable for solving the most frequently occurring failures by $[3,6,8]$. The selection was made from a repair and remediation measures database of ETICS according to [5], which can be used for several types of failures, whether in the basic alternative I (conservative), or alternative II (radical).

\section{EXPERIMENT}

Reflection of experiment work consisted in verification methodology that allows decision making in the planning process and operational solution to insulation system failures. The criteria are economic indicators expressed in price for each appropriate remediation intervention and possibility to keep or extend the lifetime of existing insulation construction.

\subsection{Input data}

Selected object for the implementation of the verification selection methodology had applied the construction of additional thermal insulation without further specification. For comparison with the 
standard requirements of the findings it shows that the object of construction insulation lagging behind in strata according to [10], [11] the following extent:

- Separation of final adjusting from reinforcing layer (formation of air bubbles in $35 \%$ of the total area).

- $\quad$ Surface cracks in the shape of a Y.

- Continuous cracks copying the position of insulation plates.

- $\quad$ Pillow effect.

Probes into strata were conducted for the specification of the materials and technologies, and they showed used material and the method of implementation as follows:

- $\quad$ The base under insulation construction consists of brickwork with cavities.

- Insulation material consists of polystyrene in the thickness of $60 \mathrm{~mm}$.

- Anchoring of insulators with the number of anchors 2 per one square meter at an object height of nine meters.

- Bonding of insulating plates on targets, when connecting insulation surface with base constitute less than min. $40 \%$ of the surface.

- The absence of diagonal grids in the corners of window openings

- Locally detected insufficient anchorage length of anchors in the base

- Incorrect way of reinforcing layer implementation in which the reinforcing grid was not covered with mortar on both sides.

Insulation age was 20 years, whilst the basic ETICS durability is 30 to 35 years according to [12]. The detection range of anomalies was after detailed diagnostics $30-50 \%$ of the total area of the facade. Functional and thermo-technical criteria of ETICS construction did not meet the present requirement for thermal insulation [11].

\subsection{Decision-making process}

The basic expectation of remediation measure is a balance of the investments made to the lifetime of the intervention. Proposal of variant remediation measures resulting from research and diagnosis is as follows:

I. Total remediation - reconstruction of the building construction,

II. Additional insulation construction, "re-insulation" of already existing ETICS renovation of existing ETICS construction,

III. New reinforcing layer - the repair of ETICS construction.

Alternative technologies enter into the decision-making process, and they are considered to meet the required technical criteria for insulation and also the feasibility in the given conditions (reconstruction, restoration, and repair).

\subsection{Impact of remediation methods on the lifetime of the ETICS}

Any technical intervention into the building structure has own economic dimension, which can be represented by the costs and causes prolonged physical lifetime of the construction [7]. Knowing the cost of remedial measure (No), knowledge of first cost of building construction (C), residential value of construction $(\mathrm{H})$ and basic residential value of construction $(\mathrm{Tz})$ extending of lifetime can be determined $(\Delta \mathrm{T})$ as follows [7].:

$$
\Delta T=T z * N o / H \quad \text { [year] }
$$


Conditions of correct results of expressed residential life are a reflection of the cost of repairs at the same price level as the cost of acquisition.

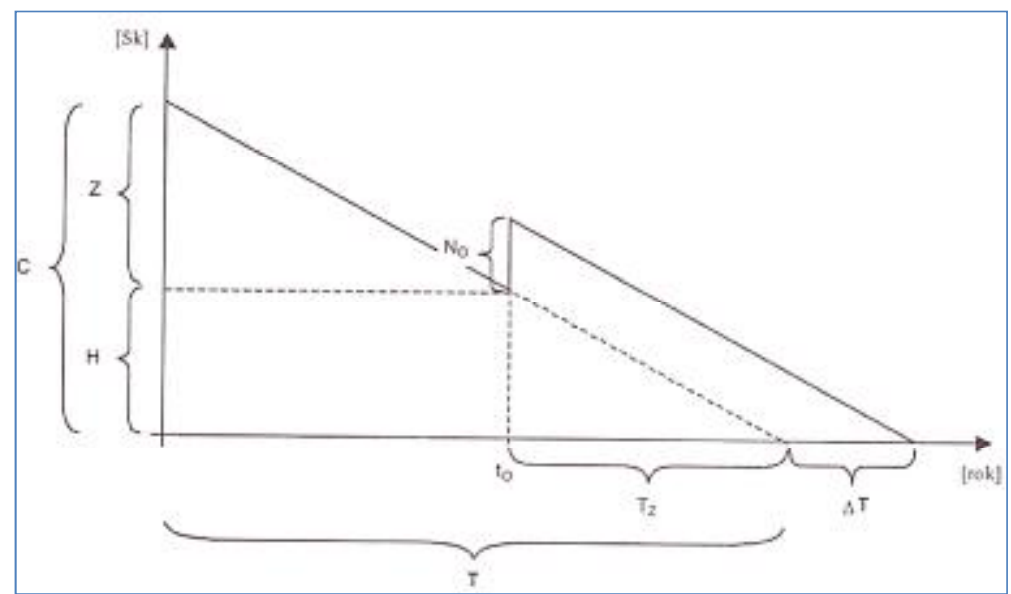

Fig. no.3: Relationship of remediation interventions for extending the lifetime of the construction [7]

Relationship No.1 [7] has been used for reflecting the impact of the remediation method selection for the lifetime of the building structure, and shows the impact on the investments involved in building or construction on the overall lifetime of the building and its extension. Costs (No) in this case are an estimate of the cost of implementation of alternative remediation measures. The costs expressed taking into account economic criteria for the selection of remediation measures. Basic durability is considerate into the calculation, taking into account the actual technical condition of the lower level interval according to [14], which corresponds to 30 years.

\begin{tabular}{|cc|r|r|}
\hline & Alternative technologies & \multicolumn{1}{c|}{$\begin{array}{c}\text { Total labour } \\
\text { content } \\
{[\mathbf{N h} / \mathbf{m} 2]}\end{array}$} & \multicolumn{2}{|c|}{$\begin{array}{c}\text { Price } \\
{\left[\mathbf{f} / \mathbf{1 m}^{\mathbf{2}}\right] \text { excluding VAT }}\end{array}$} \\
\hline I. & Total remediation - (reconstruction) & 1.993 & 43.41 \\
\hline II. & "Re-insulation" (renovation) & 1.640 & 37.26 \\
\hline III. & New reinforcing layer (repair) & 1.229 & 25.60 \\
\hline
\end{tabular}

Scheme no.2: Economic indicators of alternatives solutions for insulation failures (Author)

The difference of the cost between the alternative I. and alternative II. is minimal. Alternative I becomes the new construction, from which is expected to achieve the status of the current characteristics and requirements. However, taking into consideration the age of representative building (50 years) and its basic lifetime (80 years), extend the lifetime of ETICS construction can be considered with taking into account the end of lifetime of the whole building. Reflecting the impact of the funds in the overall costs of the national team Repair surfaces to extend the life of insulation is processed according to [7] and shown in the following graph: 


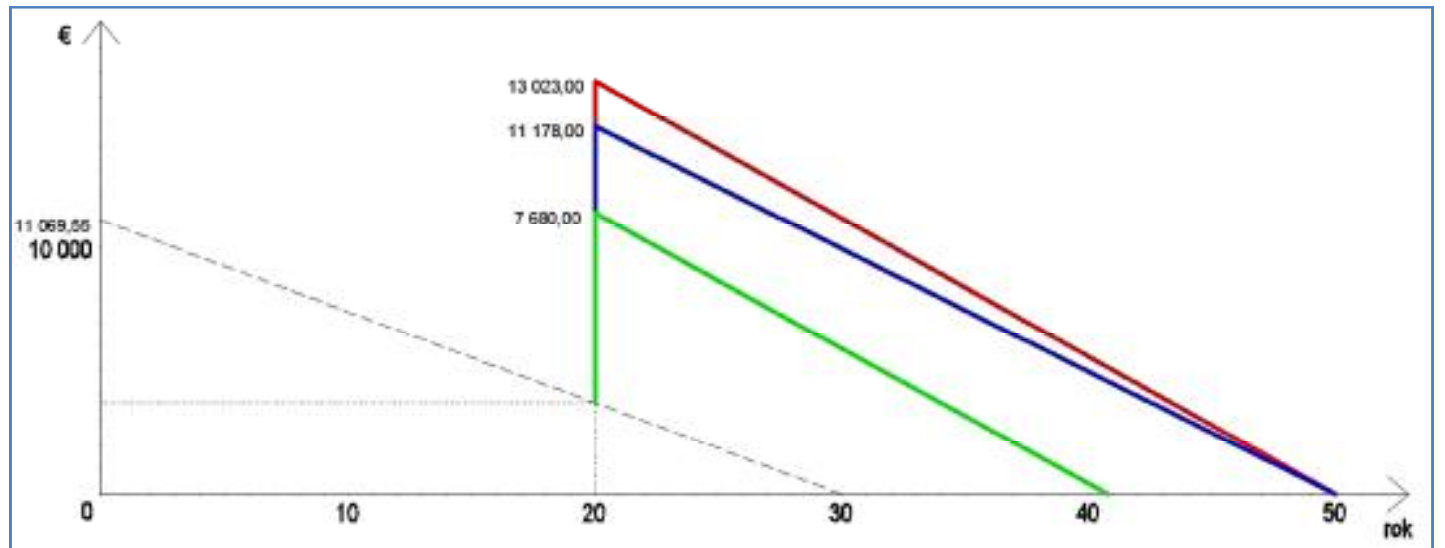

Fig. no.4: Diagram of the impact of remediation methods to extend the lifetime of the ETICS construction. Prepared by [7]. Legend: red: var. I., blue: var.II., green: var. III.

From the consideration that the overall structure is a representative age 50 and the primary life is 80 years, the life extension of the graph bounded by a maximum value of the whole life of the building. Lifetime extension when using different technologies depict below scoreboard:

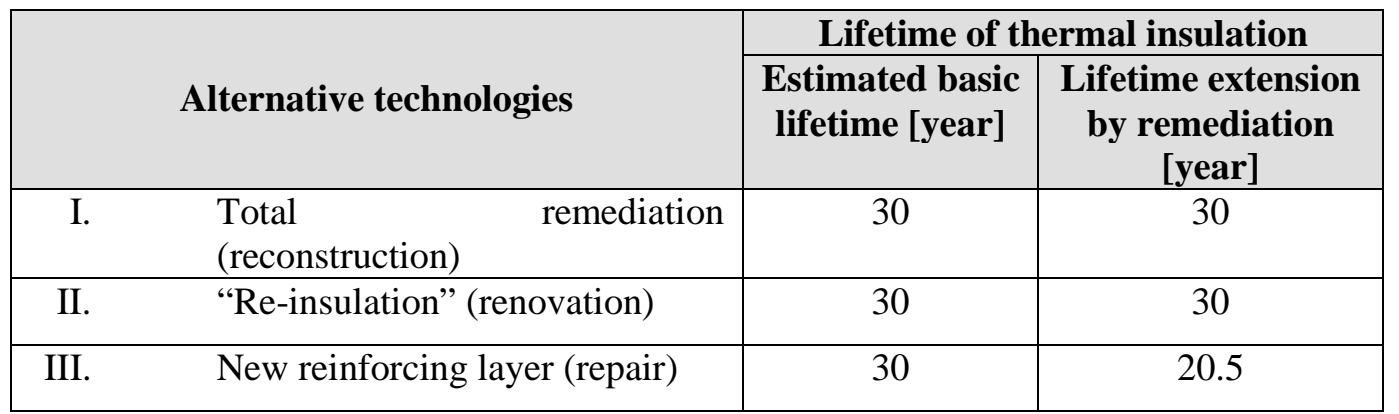

Scheme no.3: Evaluation of alternatives solutions of insulation failures in term of lifetime extension (the author)

\section{CONCLUSIONS AND DISCUSSION}

From the experiment we could assume that the selection process carried out on the base of majority position of preferred criteria delivers clear result and simple model for selection. The first two options do not show differences when assessing the impact of selection of remediation technologies on the ETICS lifetime. This condition is caused by a negligible difference of funds allocated for remediation measures as well as boundary conditions, which are given by the total remaining lifetime of the building. Last alternative with the shortest lifetime requires the lowest cost and given the overall age of the building, it is not appropriate to exclude this alternative from selection. The first two alternatives with the final effect are getting closer to the requirements for the energy performance of buildings required to 2020. It is also necessary to point out the risks of implementation arising from the stress of existing base construction by new anchorage or additional anchoring. Details solutions of overlapping construction by roof cladding, tinsmith elements, shifting the window openings into the inside lining, and thus change the course of isolines in these critical details. Other risks arise with the lack of empirical observations and proof of lifetime of remediation measures alternatives no. II and III. The lifetime extension expressed in terms of financial cost is then at the level of theoretical assumptions.

Based on experimental observations of impact selection of remediation measures on ETICS durability it is clear that the one-stage decision-making model by preferred criteria cannot be considered as final and effective process. The basic hypothesis of multi-criteria decision-making requirement was confirmed, i.e. in the decision-making process should be taken into account additional physical, 
technical and technological criteria and entry boundary conditions, despite the fact that the survey was evaluated as the criteria with the minimal importance.

\section{LITERATÚRA:}

[1] ANTOŠOVÁ, N: Životnost' a údržba zateplenia obvodového plášt’a. Vedeckoodborná konferencia. ISBN 978-80-232-0301-1,Realizácia a ekonomika stavieb. Október 2009 Trenčianske Teplice.

[2] BILČÍK, J. - DOHNÁLEK, J.: Sanace betonových konstrukcí, Bratislava 2003, str. 23,Vydavatel'stvo Jaga group, v.o.s., ISBN 80-88905-24-9

[3] GREGUŠ, M.: Technologické riziká pri realizácií kontaktných zateplovacích systémov, Bratislava 2010

[4] MLYNAROVIČ, V. - HOZLÁR, E.: Viackriteriálne rozhodovanie, Ekonomická univerzita v Bratislave, 1993

[5] PETRO, M.: Kontaktné zateplovacie systémy (ETICS) - Poruchy a ich odstránenie, Vydavatel'stvo Tribun EU 2013, ISBN: 978-80-263-0539-2

[6] SLOBODA, P.: Nejčastejší nedostatky př̌i provádení vnějších tepelně izolačních kontaktních systému (ETICS) a jejich následné poruchy. S-Therma Olomouc, 01/2007

[7] SOMOROVÁ, V. a kol.: Optimalizácia nákladov spravovania stavebných objektov metódou facility managementu, Bratislava 2007, str. 123, Vydavatel'stvo STU Bratislava, ISBN 978-80$227-2782-2$

[8] WITZANY, J. - ČEJKA, T. - PAŠEK, J. - ZIGLER, R., Průzkum vad a poruch povrchové úpravy kontaktního zateplovacího systému na vybraných panelových objektech, In: Setkání kateder a ústavů pozemního stavitelství ČR a SR. Praha: Fakulta stavební ČVUT v Praze, 2005, s. $1-8$

[9] STN 73 2901: Zhotovovanie vonkajších tepelnoizolačných kontaktných systémov (ETICS), SUTN, Bratislava 2008

[10] STN 73 2902: Vonkajšie tepelnoizolačné kontaktné systémy (ETICS). Navrhovanie a zhotovovanie mechanického pripevnenia na spojenie s podkladom.

[11] STN 730540 1-4: Tepelnotechnické vlastnosti stavebných konštrukcií a budov. 2002

[12] ETAG 004: Vonkajšie zložené tepelnoizolačné systémy s omietkou (ETICS), Európska organizácia pre technické osvedčovanie, 2004 